\title{
Effects of Aspartame on the Exocrine Pancreas of Rat Fetuses
}

\author{
Efectos del Aspartame en el Páncreas Exocrino de Fetos de Ratas
}

Fabíola Azevedo Genovez de Lima Leme \& Reinaldo Azoubel

\begin{abstract}
LEME, L. F. A. G. \& AZOUBEL, R. Effects of aspartame on the exocrine pancreas of rat fetuses. Int. J. Morphol., 24(4):679-684, 2006.

SUMMARY: The present study evaluated the effects of the sweetener aspartame on the fetal pancreas, through a morphometric study, with the objective of studying the exocrine pancreas at the end of gestational development. For this we utilized two treated groups, one with a solution of aspartame at ambient temperature and the other with an aspartame solution heated to $40^{\circ} \mathrm{C}$, and two groups treated with water ad libitum, at ambient temperature and heated to $40^{\circ} \mathrm{C}$, respectively. On the final day of gestation the fetuses were removed and the pancreas was collected for microscopic analysis. The morphometric study demonstrated alteration in eight out of the eleven parameters studied in the group treated with the heated solution and one parameter altered in the group treated with solution at ambient temperature.
\end{abstract}

KEY WORDS: Aspartame; Pancreas; Fetus.

\section{INTRODUCTION}

Aspartame (N-L-@-aspartyl-L phenylalanine 1methyl-ester) (Stedman's Dictionary, 1990) corresponds to one synthetic food additive, of low caloric value, formed from the union of two amino acids, aspartic acid and phenylalanine. Its sweetening power is from 180 to 200 times greater than that of sucrose and is consumed by millions of persons in approximately 6000 products such as soft drinks, chewing gum, fruit juices, gelatins and jellies (Grenby, 1991; Sanyudes, 1990; Butchko, 2002).

Discovered accidentally in 1965 by James Schlatter, the referenced substance was approved for use by the FDA in the 1970s ( Cardello et al., 2000 ) with a maximum daily intake of $20 \mathrm{mg} / \mathrm{kg}$ of body weight, but this total was increased in 1984 to $50 \mathrm{mg} / \mathrm{kg}$ of body weight as a function of data obtained in studies on humans (FDA, 1974).

Considering studies by Molinary et al. (1984), which demonstrated that the food additive was not carcinogenic, mutagenic or teratogenic, the Joint FAO (1980), the Scientific Committee for Food (1985) and the Health Protection Branch of Health and Welfare (1979) established that, given an absence of side effects up to the level of $4000 \mathrm{mg} / \mathrm{kg}$ of body weight, the maximum safe daily ingestion would be $40 \mathrm{mg} /$ $\mathrm{kg}$ of body weight.
Although studies in humans have affirmed the safety of utilizing the food additive in question, including children and the elderly (Butchko), some objections were presented at that time with respect to its toxicity. Several of the studies realized concluded that the maximum safe dose would be $34 \mathrm{mg} / \mathrm{kg}$ of body weight (Stegink, 1987).

Despite being considered practically innocuous, the appearance of adverse effects such as headaches and nausea have been reported (Koehler \& Glaros, 1998; Roberts, 1995, 1997).

According to Roberts (1996) one fifth of 830 persons that were submitted to his studies presented allergic reactions to aspartame, whose symptoms include edema of the lips, tongue and throat; urticaria, damage from respiratory allergies, and even edema of the salivary glands. These reactions may have been caused by the aspartame molecule, its three components, or by approximately 10 substances resultant from breakdown of the molecule, which occurs due to heating and prolonged storage (NTP).

The present work describes morphometric alterations of the fetal exocrine pancreas of rats submitted to ingestion of aspartame, heated or at ambient temperature, during the gestational period. 


\section{MATERIAL AND METHOD}

In this study we evaluated, in two stages, the pancreas of twenty rat fetuses. These animals were chosen randomly for the first stage, composed of five rats that received from the tenth to fourteenth day of pregnancy, through a nasogastric catheter, aspartame solution at $14 \mathrm{mg} / \mathrm{Kg}$ of body weight (treated group) and of five rats that received distilled water by the same route (control group). Subsequently, in the second stage, the pancreas of the fetuses was obtained from five rats that received in the same period of pregnancy and by the same route, solution of aspartame, also at $14 \mathrm{mg} /$ $\mathrm{Kg}$ of body weight, heated to $40{ }^{\circ} \mathrm{C}$ (heated treated group) and from five rates that received, by the same route and for the same period, distilled water at $40{ }^{\circ} \mathrm{C}$ (heated control group). On the twentieth day of gestation the animals from all the groups were weighed on a precision balance, as were their placentas, and their umbilical cords were measured. After laboratory processing, semi-seriated cuts of $6 \mu \mathrm{m}$, colored by hematoxylin and eosin, were obtained.

From each animal selected, we evaluated the nuclei of acinar cells by means of an optical microscope with a clear chamber (Leica ) with final magnification of 1240 times, contouring the elliptical structures on white sulfite paper with a number two black pencil. For determination of the major (D) and minor (d) diameters with a millimeter ruler, the following cariometric parameters were obtained: Mean geometric diameter: $\mathrm{M}=(\mathrm{D} . \mathrm{d}) 1 / 2$, the ratio $\mathrm{D} / \mathrm{d}: \mathrm{D} / \mathrm{d}$, perimeter, area (A), volume (V), V/A ratio, eccentricity, coefficient of form and index of contour.

For statistical comparison of morphometric results obtained in treated and control groups, the non-parametric Mann-Whitney test was utilized.

\section{RESULTS}

The results presented refer to the controls and groups treated with aspartame $14 \mathrm{mg} / \mathrm{kg}$ administered by orogastric catheter, on the $9^{\text {th }}, 10^{\text {th }}$ and $11^{\text {th }}$ day of pregnancy of the rat.

Values were considered statistically significant for $\mathrm{p}[\mathrm{U}]<0.048(\mathrm{U}<4)$.

Table I shows the mean values of initial and final body weights, the difference between initial and final body weights, number of fetuses, fetal body weights, placental weights and umbilical-cord measurements of rats from the controls (C) and those treated (T) with aspartame diluted at ambient temperature and at $40{ }^{\circ} \mathrm{C}$.

Statistical analysis showed no significant difference only for the parameters of fetus number and umbilical cord in the group treated with solution at ambient temperature. For the group treated with solution at $40^{\circ} \mathrm{C}$, the analysis showed significance in the difference between initial and final weights and in the weight of the placenta.

In Table II, the different nuclear parameters are displayed as mean values for the controls (C) and groups treated $(\mathrm{T})$ with aspartame diluted in distilled water at ambient temperature and at $40{ }^{\circ} \mathrm{C}$.

Analysis showed statistically significant difference in minor diameter in the group treated with solution at ambient temperature. But the group treated at $40{ }^{\circ} \mathrm{C}$ showed significance for all the parameters studied except major diameter, coefficient of form and index of contour.

Table I. Mean values for initial and final maternal body weights, difference between initial and final body weights (in grams), number of fetuses, fetal body weights (in grams), placental weights (in grams) and umbilical-cord length (in centimeters) of control (C) rats and groups treated (T) with diluted aspartame at ambient temperature and at $40{ }^{\circ} \mathrm{C}$. Test of Mann-Whitney.

\begin{tabular}{|c|c|c|c|c|c|c|}
\hline \multicolumn{7}{|c|}{ Controls and groups treated with aspartame at ambi ent temperature and at $40^{\circ} \mathrm{C}$} \\
\hline & \multicolumn{3}{|c|}{ Ambient temperature } & \multicolumn{3}{|c|}{ Temperature of $40^{\circ} \mathrm{C}$} \\
\hline & C Amb. & T Amb. & p[U]Amb. & C 40 & $\mathrm{~T} 40$ & $\mathrm{p}[\mathrm{U}] 40$ \\
\hline Initial weight & 247.8 & 229.8 & 0.048 & 240.7 & 245.5 & 0.274 \\
\hline Final weight & 333.2 & 286.4 & 0.004 & 346.1 & 338.9 & 0.421 \\
\hline $\begin{array}{l}\text { Difference between initial and } \\
\text { final weights }\end{array}$ & 85.4 & 56.6 & 0.004 & 107.4 & 93.4 & 0.004 \\
\hline Number of fetuses & 9 & 10 & 0.155 & 11 & 10.4 & 0.155 \\
\hline Fetal body weight & 3.84 & 1.76 & 0.004 & 1.907 & 2.052 & 0.155 \\
\hline Placental weight & 0.46 & 0.25 & 0.004 & 0.263 & 0.325 & 0.048 \\
\hline Umbilical cord & 1.64 & 1.86 & 0.075 & 2.00 & 1.82 & 0.345 \\
\hline
\end{tabular}


Table II. Mean values for major, minor and mean diameters $(\mu \mathrm{m})$, ratio between major and minor diameters $(\mathrm{D} / \mathrm{d})$, volume (mm3 ), area $\left(\mathrm{mm}^{2}\right)$, perimeter $(\mathrm{mm})$, volume/area ratio, eccentricity, coefficient of form and index of contour for rat fetus pancreatic acinar cell nuclei in controls (C) and those treated (T) with aspartame diluted in distilled water at ambient temperature and at $40^{\circ} \mathrm{C}$. Test of Mann- Whitney.

\begin{tabular}{|c|c|c|c|c|c|c|}
\hline \multicolumn{7}{|c|}{ Controls and groups treated with aspartame at ambient temperature and at $40 \mathrm{C}$} \\
\hline & \multicolumn{3}{|c|}{ Ambient temperature } & \multicolumn{3}{|c|}{ Temperature of $40 \mathrm{C}$} \\
\hline & C Amb. & T Amb. & $\mathrm{p}[\mathrm{U}] \mathrm{Amb}$ & C 40 & T 40 & $\mathrm{p}[\mathrm{U}] 40$ \\
\hline Major diameter & 13.50 & 13.26 & 0.345 & 14.44 & 14.38 & 0.500 \\
\hline Minor diamete $\mathrm{r}$ & 7.86 & 7.37 & 0.048 & 8.10 & 7.62 & 0.008 \\
\hline Mean diameter & 10.26 & 9.83 & 0.075 & 10.74 & 10.43 & 0.048 \\
\hline Ratio D/d & 1.76 & 1.86 & 0.075 & 1.84 & 1.93 & 0.048 \\
\hline Nuclear volume & 557.57 & 529.99 & 0.111 & 683.50 & 617.62 & 0.028 \\
\hline Nuclear area & 84.21 & 84.21 & 0.075 & 92.21 & 86.52 & 0.048 \\
\hline Perimeter & 34.21 & 33.14 & 0.111 & 36.18 & 35.44 & 0.048 \\
\hline Volume-area ratio & 6.84 & 6.56 & 0.075 & 7.16 & 6.95 & 0.048 \\
\hline Eccentricity & 0.80 & 0.82 & 0.210 & 0.81 & 0.84 & 0.028 \\
\hline Coefficient of form & 0.89 & 0.87 & 0.210 & 0.87 & 0.86 & 0.075 \\
\hline Index of contour & 3.77 & 3.81 & 0.210 & 3.81 & 3.84 & 0.210 \\
\hline
\end{tabular}

\section{DISCUSSION}

We observed that the mean initial and final body weights during the gestation of rats treated with aspartame solution at ambient temperature was significantly reduced in relation to those of rats from the control group. This reduction in weight is suggestive of diminution of caloric intake and also was observed in the gestation of rats treated with aspartame solution heated to $40^{\circ} \mathrm{C}$. However, it was noted that the group treated with heated solution presented reduced body weight reduced to a smaller quantity than the group treated at ambient temperature, suggesting that the molecules released when aspartame is heated are more easily metabolized. These results differ from those reported by Soffritti et al. (2005), who related the use of aspartame to increase in lymphomas and leukemia in female rats.

Several works realized with humans related loss in total body weight and the long-term use of aspartame. Vermunt (2003) reported that replacement of sucrose with sweeteners such as aspartame, principally in beverages, results in diminution of caloric intake and reduced body weight, besides the observation that consumption of aspartame may be associated with long-term improvement in maintenance of body weight. This result also was confirmed in a work realized with 2 groups (one that utilized aspartame and another that used ingested common sugar) by Beck (2002). This study showed that diets that include aspartame can facilitate long-term maintenance of body-weight reduction, and that persons utilizing sweetener all lost significantly more weight and regained less weight during long-term maintenance than those who did not utilize aspartame.
The fetus necessitates substrates for growth and energy production. Among these, glucose is the primary source of energy for metabolism and growth. The substances that the fetus utilizes are supplied by maternal blood and cross the placental membrane. Maternal malnutrition, principally in the final trimester, generally produces children with reduced weight. Furthermore, it is known that grave malnutrition, resultant from an inadequate diet, causes a reduction in fetal growth (Moore, 2000 and Sadler, 2000).

One factor that can influence the weight of fetuses is the quality of exchanges between the mother and fetus, effectuated by the placenta. The principal functions of the placenta are metabolism (such as synthesis of glycogen), transport of metabolic products (nutrients, electrolytes and antibodies) and gases between the maternal and fetal bloodstreams and the production of hormones such as progesterone, estrogenic hormones, hCG, human chorionic somatotropin (a hormone similar to the growth hormone that gives the fetus priority in receiving glucose from the maternal bloodstream and makes the mother slightly diabetogenic) (Moore; Sadler).

In the present work we observed that the mean placental weight of animals treated with aspartame solution at ambient temperature was significantly diminished in relation to that of the control group. Such reduction can be related to the placental junction and consequent diminution of the total area available for exchange. It is known that defects of the placenta can provoke diminution in the total area available for exchange of nutrients between the fetal 
and maternal blood flows, causing reduction in weight of the child among other effects (Moore and Sadler).

In the present study we observed that in the group treated with aspartame at ambient temperature, there was diminution in body weight (and weight of the placenta). This reduction can indicate that the fetuses cannot supply the requirements for substrates, including glucose, which either by possible diminution in the blood of rats that utilized sweetener or by possible reduction of the placental area, provoking a quantity of exchanges that is less than ideal for the fetus. The result obtained by the placental weight parameter was significant in the group treated with aspartame solution at $40^{\circ} \mathrm{C}$. The mean placental weight of the treated group was greater and, although not statistically significant, the mean weight of the treated group also was higher that that of the control, a result different from that obtained by Portela (2004) who found significant diminution of weight and placenta for the groups treated with aspartame at $40^{\circ} \mathrm{C}$ and also at ambient temperature.

The length of the umbilical cord has been considered an indicator of fetal movement and, consequently, it is related to the space within the uterine cavity (Portela, 2004). It is accepted that umbilical-cord length is influenced by genetic and other factors. In humans, the existence of excessively long or short cords are uncommon. Despite this, short cords can provoke premature separation of the placenta from the uterine wall during parturition (causing difficulties during parturition by pulling the placenta from its insertion in the uterus), whereas in the case of a longer cord, prolapse can occur and it can be twisted, provoking fetal hypoxia or anoxia (enabling, for example, cerebral lesion) (Moore and Sadler). The present study did not present statistically significant results in umbilical-cord length of the treated groups. These results differ from those found by Portela, where it was observed that the cords of groups treated with aspartame solution, both at ambient temperature and solution heated to $40^{\circ} \mathrm{C}$, were diminished.

In the group treated with heated solution, values for minor diameter, major diameter, the ratio between major and minor diameters, nuclear volume, nuclear area, perimeter, ratio between volume and area, and eccentricity were considered statistically significant compared to the control group, suggesting the existence of problems in the functioning of the exocrine pancreas. The parameters major diameter, coefficient of form and index of contour did not present statistically significant results.

Minor diameter was the only parameter to present a statistically significant result for the group treated with aspartame solution at ambient temperature. According to works of Padovani Junior et al. (2005), this finding would be a reliable indicator of exocrine pancreas physiopathology. Thus the results suggest that the use of aspartame heated to $40^{\circ} \mathrm{C}$ by rats at the $9^{\text {th }}, 10^{\text {th }}$ and $11^{\text {th }}$ day of pregnancy altered the development of the exocrine pancreas of fetuses, a fact that was observed less in the group treated with aspartame solution at ambient temperature. These results differ from a study realized by Portela (2004), where aspartame at ambient temperature was demonstrated to be more noxious to hepatic cells than the heated solution.

The fact that solution of heated aspartame probably causes more modifications in the fetal exocrine pancreas may be related to extra-corporal decomposition of this substance. The studies demonstrated that the sweetener suffers decomposition at high temperatures and photodecomposition in aqueous solutions. In this manner, rats treated with heated solution may have ingested the components of aspartame, which are aspartate, phenylanine and methanol, subsequently it is converted into formaldehyde and formate (NTP). One difficulty related to metabolites of aspartame concerns phenylanine. The phenylketonuria is a recessive hereditary disease in which the carrier does not metabolize phenylanine, enabling a clinical picture of hyperphenylalanine. It was observed that in these diseases large quantities of this substance can cause mental retardation, microcephaly and congenital cardiopathy (Cotran, 2000). Another possible problem related to the use of aspartame is the release of methanol (and derivatives) in the decomposition of the sweetener. Some harmful effects of methanol and its derivatives on the organism were demonstrated. According to a study realized by Oyama et al. (2002) on the ingestion of aspartame at elevated doses, formaldehyde, a metabolite of methanol, in excess, induces cell death. Sofritti et al. (2002) related ingestion of formaldehyde in drinking water to the yellowing of skin in rats and, subsequently, this cutaneous alteration also was observed in animals exposed to solutions with high concentrations of aspartame. Furthermore, it was verified that the use of sweetener at doses close to those utilized by humans caused increase in lymphomas and leukemia in rats (Sofritt et al., 2005).

It is important to emphasize that once decomposed, the components of sweetener are dispersed among the products that were sweetened. In this manner, sweetened foods and beverages that were heated when transported or stored and that contain sweetener in their formulation, possess the amino acids aspartate, phenylanine and methanol, and their derivatives (formaldehyde and formate) in liberated form, thus enabling their ingestion.

It is not possible to extrapolate the results obtained in this experiment with rats to humans. Nevertheless, it may 
be suggested that the effects of the heated aspartame solution on the human organism would be the same as those of a beverage that was heated during its transport.

Cariometry and morphometry supplied data that demonstrate more frequent and statistically significant modifications in exocrine pancreatic cells of the group treated with solution of aspartame heated to $40^{\circ} \mathrm{C}$. Less frequent alterations were observed in the group treated with aspartame solution at ambient temperature.

Based on the results obtained, administration to rats on the $9^{\text {th }}, 10^{\text {th }}$ and $11^{\text {th }}$ day of pregnancy at $14 \mathrm{mg} / \mathrm{kg}$ body weight of aspartame diluted in distilled water at ambient temperature caused diminution of maternal weight and weights of the fetus and placenta. Morphometry showed an alteration in the minor diameter of the nucleus.

Aspartame diluted in distilled water at a temperature of $40^{\circ} \mathrm{C}$ also originated diminution of maternal weight. Other effects of administration of this solution were augmentation of placental weight and alteration of the following parameters: minor diameter, mean diameter, the ratio between major and minor diameter, nuclear volume, nuclear area, perimeter, and the relation among volume, area and eccentricity.

LEME, L. F. A. G. \& AZOUBEL, R. Efectos del aspartame en el páncreas exocrino de fetos de ratas. Int. J. Morphol., 24(4):679-684, 2006.

RESUMEN: El presente estudio evalúa los efectos del endulzante aspartame en el páncreas fetal de rata, a través del estudio morfométrico, con el objetivo de conocer el páncreas exocrino al final del desarrollo gestacional. Fueron utilizados dos grupos tratados, uno con una solución de aspartame a temperatura ambiente y otro con una solución de aspartame calentada a $40^{\circ} \mathrm{C}$, y dos grupos tratados con agua ad libitum, a temperatura ambiente y calentada a $40{ }^{\circ} \mathrm{C}$, respectivamente. En el último día de gestación los fetos fueron removidos y el páncreas fue extraído para el análisis microscópico. El estudio morfométrico demostró alteraciones en ocho de los once parámetros estudiados en el grupo tratado con solución de aspartame calentada y un parámetro alterado en el grupo tratado con solución a temperatura ambiente.

PALABRAS ClAVE: Aspartame; Páncreas; Fetos.

\section{REFERENCES}

Beck, B; Burlet, A.; Max, J.P. \& Stricker-Krongrad, A. Effects of long-term ingestion of aspartame on hypothalamic neuropeptide Y, plasma leptin and body weight gain and composition. Physiol. Behav., 75(12):41-7, 2002.

Butchko, H. H.; Stargel, W. W.; Comer, C. P.; Mayhew, D. A.; Benninger, C.; Blackburn, G.L., et al. Aspartame: Review of safety. Regul. Toxicol. Pharmacol., 35 (2 PT 2):S1-93, 2002.

Cardello, H. M. A. B.; Silva, M. A. A. P. \& Damásio, M. H. Análise descritiva quantitativa de sweeteners em diferentes concentrações. Ciênc. Tecnol. Aliment., 20(3):31828,2000 .

Cotran, R. S.; Kurmav, V. \& Collins, T. Robbins Patologia Estrutural e funcional. 6 ed. Rio de Janeiro, Guanabara Koogan, 2000. pp. 426-7.

Food and Drug Administration (FDA). Food additives permitted in food for human consumption: Aspartame. Fed. Regist., 39:27317-20, 1974.
Grenby, T. H. Update on low calories sweetenerd to benefit dental health. Int. Dent. J., 41(4):217-24, 1991.

Health and Welfare Canada. Proposal on aspartame [Carta $N^{\circ}$ 564]. Health Protection Branch, 1979.

Joint FAO/WHO Expert Committee on Food Additives (JECFA). Aspartame: toxicological evaluation of certain food additives. In: WHO Food Additive Series. Geneva, (15):18-86, 1980

Koehler, S. M. \& Glaros, A. The effects of aspartame on migraine headache. Headache, 28(1):10-4, 1998.

Molinary, S.V. Preclinical studies os aspartame in nonprimate animals. In: Stegink, L. D.; Filer, L. J. editors. Aspartame: physiology and biochemistry. New York: Marcel Dekker; 1984. pp. 289-306.

Moore, K. L. Embriologia clínica. 4.ed. Rio de Janeiro, Guanabara Koogan, 2000.

Oyama, Y.; Sakai, H.; Arata, T.; Okano, Y.; Akaike, N. \& 
Sakai, K. Cytotoxic effects of methanol, formaldehyde, and formate on dissociated rat thymocytes: a possibility of aspartame toxicity. Cell Biol. Toxicol.,18(1):43-50, 2002.

Padovani Junior, J. A.; Azoubel, R.; Martins, A. T. \& Maniglia, J.V. Value of morphometry in prognosis of laryngeal neoplasms. Int. J. Morphol., 23(3):275-8, 2005.

Portela, G. S. Effects of aspartame sobre o body weight e fígado de ratos. (Dissertação). Faculdade de Medicina de São José do Rio Preto. 2004.

Roberts, H. J. Aspartame and brain cancer. Lancet, 349 (9048):362, 1997.

Roberts, H. J. Aspartame and headache. Neurology, 45 (8):1631-3, 1995.

Roberts, H. J. Aspartame as a cause of allergic reactions, including anaphylaxis. [Carta]. Arch. Intern. Med., 13, 156:1027, 1996.

Sadler, T. W. Embriologia médica. 8.ed. Rio de Janeiro, Guanabara Koogan, 2000.

Sanyudes, S. Alternative sweeteners. Can. Pharmaceutical J., 123:455-60,1990.

Scientific Committee for Food (SCF). Food science and techniques. In: Reports os Scientific Committee for Food, sixteenth series. Commission of the European Communities, Luxembourg. 1985.

Soffritti, M.; Belpoggi, F.; Esposti, D. D.\& Lambertini, L. Aspartame induces lymphomas and leukaemias in rats. Eur. J. Oncol., 10(2), 2005.

Soffritti, M.; Belpoggi, F.; Lambertini, L. et al. Results of longterm experimental studies on the carcinogenicity of formaldehyde and acetaldehyde in rats. In Mehlman, M.A.; Bingham, E.; Landrigan, P. J. et al. Carcinogenesis bioassays and protecting public health. Commemorating the lifework of Cesare Maltoni and colleagues. Ann. NY. Acad. Sci., 982: 87-105, 2002.

Stedman's Medical Dictionary. $25^{\text {th }}$ ed. Baltimore, Williams \& Wilkins, 1990. pp.117.

Stegink, L. D. Aspartame-sweetened beverage: effect on plasma aminoacid concentration in normal adults hetrerozygous for fenylketonuria. J. Nutr., 117:1989-95, 1987.
Vermunt, S. H.; Pasman, W. J.; Schaafsma, G.\& Kardinaal, A. F. Effects of sugar intake on body weight: A review. Obes. Rev., 4(2):91-9, 2003.

Correspondence to:

Prof. Dr. Reinaldo Azoubel

Faculdade de Medicina de São gosé do Rio Preto

Av. Brigadeiro Faria Lima 5416

CEP 15090-000

Säo gosé do Rio Preto - $S P$

BRASIL

Email:guilherme@famerp.br

Received: 18-06-2006

Accepted: 18-08-2006 